\title{
SPATIAL DISTRIBUTION OF PRODUCTIVE, ENVIRONMENTAL, AND SOCIOECONOMIC FACTORS TO DISCRIMINATE DAIRY CATTLE PRODUCTION IN THE SOUTH OF BRAZIL
}

\section{ESPACIALIZAÇÃO DOS FATORES PRODUTIVOS, AMBIENTAIS E SOCIOECONÔMICOS PARA DISCRIMINAR A PRODUÇÃO DE BOVINOS LEITEIROS NO SUL DO BRASIL}

\author{
Heitor José Cervo ${ }^{1}$ \\ Vanessa Peripolli2* \\ Bárbara Bremm ${ }^{1}$ \\ Julio Otávio Jardim Barcellos ${ }^{1}$ \\ João Batista Souza Borges ${ }^{1}$ \\ Concepta McManus ${ }^{3}$ \\ ${ }^{1}$ Universidade Federal do Rio Grande do Sul, Porto Alegre, RS, Brazil. \\ 2Instituto Federal Catarinense, Araquari, SC, Brazil. \\ ${ }^{3}$ Universidade de Brasília, Brasília, DF, Brazil. \\ *Corresponding author - vanessa.peripolli@hotmail.com
}

\begin{abstract}
The South region of Brazil differs from the others due to its high milk production rates. Production heterogeneity, climate and soil diversity, and environmental and socioeconomic circumstances contribute to differentiate political-administrative regions. In this study, we aimed to spatialize the production, environmental, and socioeconomic factors that best discriminate bovine milk production in the states of the South of Brazil. Multivariate analyses were performed to discriminate both the studied variables and the mesoregion and cities of these states. The Western Catarinense and Northwestern Rio-grandense mesoregions showed the highest production indices, but they were discriminated at a low level (35.76\%). The formation of clusters showed that Casca, Marau, and Santo Cristo from the Northwestern Riograndense and Concordia, Coronel Freitas, Palmitos, and São Lourenço do Oeste from the Western Catarinense mesoregion had higher production indices. The municipal clusters were discriminated at a high level by production (98.24\%) and by environmental and socioeconomic $(72.75 \%)$ factors. Production variables were the most important for local clusters discrimination. The specificities and peculiarities to each region were evidenced through the heterogeneity of production and environmental and socioeconomic factors. Therefore, it is necessary to design and implement specific technological innovations to each region to maximize productive efficiency and minimize adverse environmental effects in dairy herds.
\end{abstract}

Keywords: cluster; multivariate analysis; principal components; spatialization.

\section{Resumo}

A região Sul se diferencia das demais por ter maior produtividade de leite. A heterogeneidade da produção, a diversidade edafoclimática e ambiental, e as distintas realidades socioeconômicas contribuem para diferenciar as regiões político-administrativas. Objetivou-se espacializar os fatores produtivos e os fatores 
ambientais e socioeconômicos que melhor discriminam a produção de leite de vaca nos estados do Sul do Brasil. Análises multivariadas foram realizadas para discriminar tanto as variáveis em estudo quanto as mesorregiões e municípios destes estados. As mesorregiões Oeste Catarinense e Noroeste Rio-grandense apresentaram os melhores índices de produção, mas foram discriminadas em baixo nível (35,76\%). A formação de cluster por municípios mostrou que Casca, Marau e Santo Cristo da mesorregião Noroeste Rio-grandense e Concórdia, Coronel Freitas, Palmitos e São Lourenço do Oeste da mesorregião Oeste Catarinense apresentaram melhores índices produtivos. Os clusters municipais foram discriminados em alto nível pelos fatores produtivos $(98,24 \%)$ e pelos fatores ambientais e socioeconômicos $(72.75 \%)$. As variáveis produtivas foram as mais importantes na discriminação dos clusters municipais. As especificidades e peculiaridades específicas a cada região foram evidenciadas por meio da heterogeneidade dos fatores produtivos, ambientais e socioeconômicos. Portanto, faz-se necessário conceber e implementar inovações tecnológicas específicas à cada região para maximizar a eficiência produtiva e minimizar os efeitos ambientais adversos em rebanhos leiteiros.

Palavras-chave: análise multivariada; componentes principais; cluster; espacialização

Received on: December 9th, 2014

Accepted on: November 6th, 2017

\section{Introduction}

Reducing external factors that negatively affect production is important for the improvement of the efficiency and competitiveness in dairy farming. Farmers generally try to reduce the negative effects of environmental (soil and climate, vegetation and geomorphology), socioeconomic (gross domestic product and population), and technological factors (knowledge on factors such as nutrition, management, reproduction, and health) to obtain better results ${ }^{(1)}$.

Milk production is affected by both genetic and environmental factors. The latter comprises aspects such as temperature, air humidity, photoperiod, altitude, and precipitation, which lead to changes in technology and management use. Socio-economic factors also have an effect on milk production, influencing the choice of the production system and its productivity.

Brazil is a continental-sized country that features a wide variety of climates, besides having economic, social, political and cultural diversity. This contributes to a variety of dairy farming, production systems and use of technologies in the territories. The wide distribution of milk production ${ }^{(2)}$ leads to heterogeneity in production systems, producing a spatial distribution of productivity ${ }^{(3)}$. This heterogeneity contributes to lack of information on geographic distribution and the factors that interfere with milk production.

The interaction between environment and production leads to changes in the production systems at different levels and can influence farmers to increase, change or abandon the system. Climate change can also cause the need for adaptations within the production system. Uderstanding these factors, reducing their effects, and using them as indicators for decision making are necessary actions to increase production efficiency. Joost et al. ${ }^{(4)}$ and Lopes et al. ${ }^{(5)}$ showed the use of joining several variables in a spatial model to better understand animal production systems.

Therefore, the objective of the present study was to spatialize production, environmental, and socioeconomic factors to better understand milk production in Rio Grande do Sul and Santa Catarina states in Brazil. 


\section{Material and Methods}

This survey was conducted in the states of Rio Grande do Sul (RS) and Santa Catarina (SC). The production, environmental, and socioeconomic factors that differentiate dairy cattle production among 789 municipalities and 13 mesoregions composing these states were spatialized.

Data were extracted from the Agricultural Census $2006^{(6)}$ from Brazilian Institute of Geography and Statistics, National Institute of Meteorology, National Institute for Space Research, United States Geological Survey, and the United Nations Program for Development ${ }^{(6-10)}$. The year of 2006 was considered. For data analysis, municipality and mesoregions were used as the basis of the study. New variables were created for production depending on the area, gross domestic product, and human population of the regions.

The variables were standardized by means of the STANDARD procedure, assuming the mean zero and variance one in SAS (Statistical Analysis System, Cary, NC, USA, v.9.3). Clusters of mesoregions and municipalities were formed according to production levels (PROC CLUSTER, TREE).

Canonical variable analysis (CANCORR, CANDISC) was used to discriminate groups of clusters, mesoregions, and municipalities in the dataset. A factor analysis (PROC FACTOR) was performed to better understand the correlation structure and the sources of variation. In this analysis, the assumption was tested by the Kaiser-Meyer-Olkin $(\mathrm{KMO})^{(11)}$ orthogonality criterion. Squared multiple correlations (SMC) were used to improve the explanation of each factor on the total variance. We used the scree test to establish the minimum number of variables to be considered. Discriminant analysis (PROC DISCRIM, STEPDISC) was used to verify the use of variables to differentiate among mesoregions ${ }^{(12)}$.

\section{Results and Discussion}

The number of milked cows per effective herd size determines the greatest number of dairy cows by total herd and explains the greatest effectiveness of production systems. Therefore, in this study, there was no difference among mesoregions for milked cows per effective herd size (Table 1). However, the mesoregions of Western Catarinense (W_SC) and Northwestern Rio-grandense (NW_RS) had the highest number of milked cows and the higher amount of milk among the mesoregions evaluated. These factors indicated that these two mesoregions were the most efficient and specialized in the milk activity in RS and SC states. 
Table 1. Least squared means per municipality within the mesoregion for milked cows, amount of milk, productivity and \% of milked cows in the herd

\begin{tabular}{|c|c|c|c|c|}
\hline Mesoregion & $\begin{array}{c}\text { Milked } \\
\text { Cows } \\
\text { (head) }\end{array}$ & $\begin{array}{c}\text { Milk } \\
(1,000 \\
\text { liters })\end{array}$ & $\begin{array}{l}\text { Productivity } \\
\text { (L/cow/year) }\end{array}$ & $\begin{array}{c}\text { Milked Cows/ } \\
\text { Effective Herd } \\
(\%)\end{array}$ \\
\hline W_SC & $4762.4^{\mathrm{a}}$ & $13720^{\mathrm{a}}$ & $2859.0^{\mathrm{a}}$ & 26.19 \\
\hline SE_RS & $3991.9^{\mathrm{ab}}$ & $6043^{\text {bcd }}$ & $1512.1^{\text {bede }}$ & 21.24 \\
\hline NW_RS & $3921.5^{\mathrm{ab}}$ & $10275^{\mathrm{ab}}$ & $2604.8^{\mathrm{a}}$ & 23.65 \\
\hline SW_RS & $3807.5^{\mathrm{ab}}$ & $7000^{\mathrm{bc}}$ & $1726.9^{\text {bcd }}$ & 31.79 \\
\hline NE_RS & $2953.2^{\mathrm{abc}}$ & $6925^{\text {bc }}$ & $2791.1^{\mathrm{a}}$ & 21.52 \\
\hline ME_RS & $2502.0^{\text {bed }}$ & $5511^{\mathrm{bcd}}$ & $1993.4^{b}$ & 21.70 \\
\hline MW_RS & $2382.3^{\text {bcd }}$ & $2943^{\mathrm{cd}}$ & $1173.5^{\mathrm{e}}$ & 24.57 \\
\hline Highlands_SC & $2375.4^{\mathrm{bcd}}$ & $3348^{\mathrm{cd}}$ & $1295.0^{\text {de }}$ & 22.10 \\
\hline S_SC & $2269.4^{\text {bcd }}$ & $4069^{\mathrm{cd}}$ & $1637.7^{\text {bede }}$ & 21.27 \\
\hline Itajaí Valley_SC & $2254.7^{\mathrm{bcd}}$ & $3807^{\mathrm{cd}}$ & $1727.1^{\text {bcd }}$ & 24.02 \\
\hline Greater Flor_SC & $1851.7^{\mathrm{cd}}$ & $2486^{\text {cd }}$ & $1390.9^{\text {cde }}$ & 24.52 \\
\hline N_SC & $1535.3^{\mathrm{cd}}$ & $3138^{\mathrm{cd}}$ & $1801.5^{\mathrm{bc}}$ & 26.58 \\
\hline POA Met_RS & $755.1^{\mathrm{d}}$ & $1453^{\mathrm{d}}$ & $1736.8^{\text {bcd }}$ & 23.89 \\
\hline CV $(\%)$ & 84.42 & 94.45 & 31.34 & 76.84 \\
\hline Mean & 3033.45 & 7154.81 & 2173.35 & 23.89 \\
\hline
\end{tabular}

abde Different superscripts in a column indicate statistically significant difference $(\mathrm{p}<0.05)$ between the mesoregions using Tukey test. CV: coefficient of variation.

Abbreviations: W_SC: Western Catarinense mesoregion; SE_RS: Southeast Rio-grandense mesoregion; NW_RS: Northwestern Rio-grandense mesoregion; SW_RS: Southwest Rio-grandense mesoregion; NE_RS: Northeast Rio-grandense mesoregion; ME_RS: Mideast Rio-grandense mesoregion; MW_RS: Midwest Rio-grandense mesoregion; Highlands_SC: Highlands Catarinense mesoregion; S_SC: Southern Catarinense mesoregion; Itajai Valley_SC: Itajai Valley Catarinense mesoregion; Greater Flor_SC: Greater Florianópolis Catarinense mesoregion; N_SC: North Catarinense mesoregion; POA Met_RS: Porto Alegre Metropolitan Rio-grandense mesoregion.

The highest productivity per area, per gross domestic product and per population were observed in the mesoregions of Eestern Catarinense (W_SC) and Northeast Rio-grandense (NE_RS) (Table 2). Also, the Western Catarinense mesoregion (W_SC) presented the highest number of head of milked cows per area, amount of milk per area, amount of milk per gross domestic product, amount of milk per population and milked cows per effective herd per gross domestic product among the mesoregions evaluated. The highest number of head of milked cows per gross domestic product and of milked cows per population was observed in the Southeast Rio-grandense mesoregion (SE_RS) among the mesoregions evaluated. The Southwest Riograndense (SW_RS) and the Western Catarinense (W_SC) mesoregions presented the higher number of milked cows per effective herd per area. 


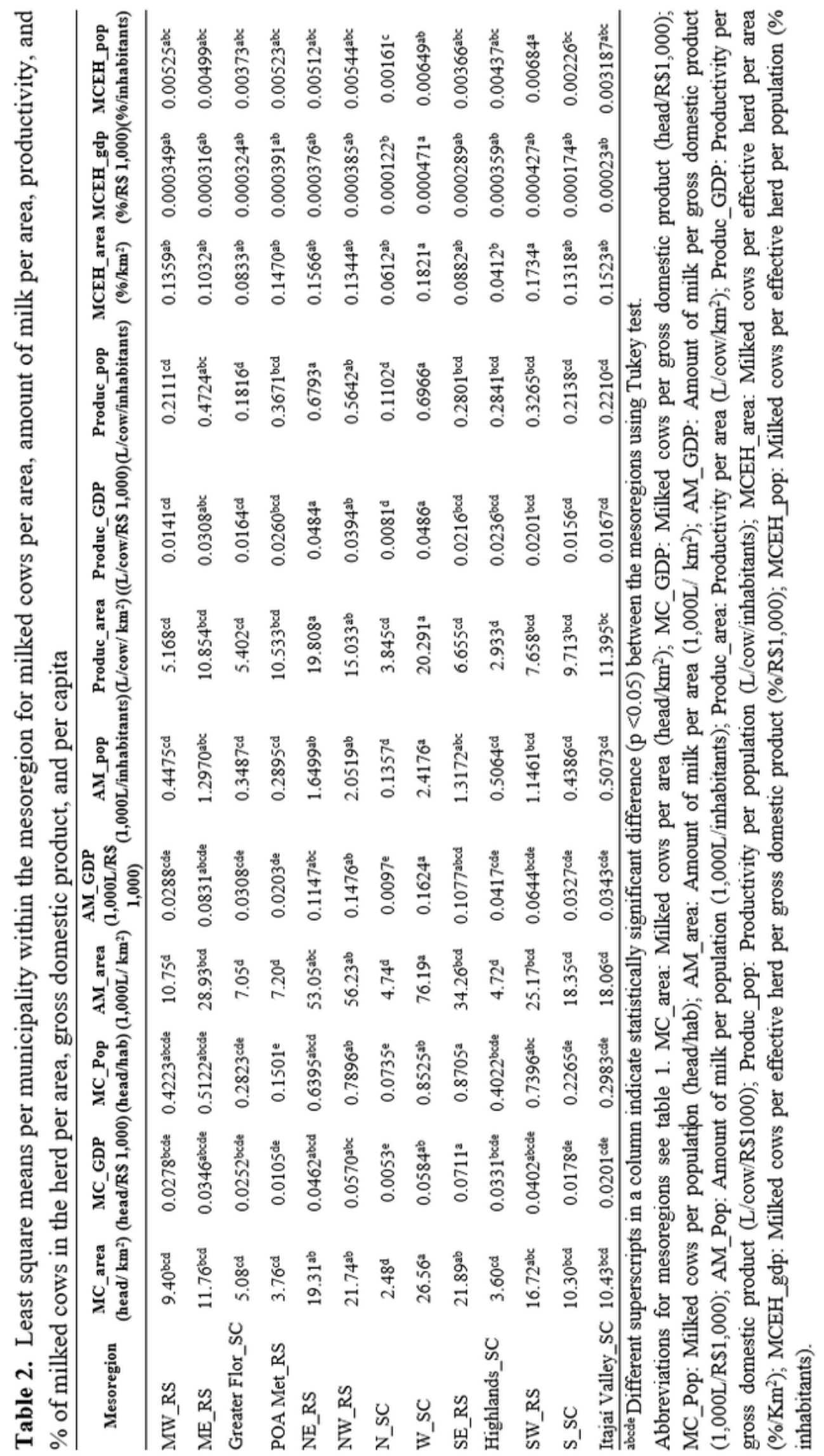


These differences observed among the mesoregions (Tables 1 and 2) were attributed not only to the specialization of production systems, environmental effects, and socioeconomic peculiarities in each region ${ }^{(13,14)}$, but also to the use of biotechnology with technical guidance, the level of information of producers, and the demand for this product ${ }^{(15)}$. Several authors showed that environmental factors affected the level of production and productivity ${ }^{(13,14)}$. The adoption of technologies such as management practices and techniques for animal breeding contributed to the intensification of production systems ${ }^{(15-17)}$. Also, the differences among the cows milked, production and productivity among mesoregions arise from distinctions among different types of herds.

The higher levels of productivity (produc_area, produc_GDP, and produc_pop; Table 2) were observed in Western of Catarinense (W_SC) and Northwestern of Rio-grandense (NW_RS). These results reflect the productive efficiency of dairy herds in these two mesoregions, showing greater livestock specialization, processes intensification and the economic and social importance of these regions ${ }^{(18)}$. Moreover, regions with higher gross domestic product and a larger number of people demand more animal products ${ }^{(19)}$.

Southeast (SE_RS), Southwest Rio-grandense (SW_RS), and Northeast Rio-grandense (NE_RS) showed no differences to the most productive mesoregions-Western Catarinense (W_SC) and Northwestern Rio-grandense (NW_RS)-for milked cows and their relationships by area, gross domestic product, and per capita; however, they showed lower production (Tables 1 and 2). Southwest Rio-grandense (SW_RS) was less specialized for milk production, characterized by subsistence or small-scale production ${ }^{(3)}$. Both Southeast (SE_RS) and Southwest Riograndense (SW_RS) were more specialized in meat production, having 50\% of the total number of cattle in Rio Grande do Sul state and only $3 \%$ of cows milked in the effective herd ${ }^{(20)}$. However, Southeast Rio-grandense (SE_RS) did not differ from Western Catarinense (W_SC) and Northwestern Rio-grandense (NW_RS) in productivity (L/cow/year; Table 1). These two mesoregions were characterized by the presence of large farms with lower rates of economic growth. The economy was not diversified, being based on the primary sector, having been colonized by immigrants and therefore with cultural differences compared to the northern half of Rio Grande do Sul state ${ }^{(21)}$.

Mideast Rio-grandense (ME_RS) and Midwest Rio-grandense (MW_RS), despite having smaller dairy herds, production and productivity than Western Catarinense (W_SC), did not differ from other more productive mesoregions (W_SC and NW_RS) in terms of production per gross domestic product and per population. These results showed that these mesoregions had smaller dairy herd, milk production, and productivity, lower gross domestic product and number of inhabitants ${ }^{(21)}$.

Metropolitan Porto Alegre mesoregion (POA_Met_RS) had smaller herd, amount of milk, milked cows per population and amount of milk per area among all mesoregions evaluated, but it did not differ from Greater Florianopolis Catarinense mesoregion (Greater Flor_SC). These mesoregions concentrate large cities, industrial parks, and shopping malls. The herd in this region showed little specialization ${ }^{(3)}$.

The value of Kaiser-Meyer-Olkin (KMO), which represents a measure of adequacy of the sample to the factor analysis (PROC FACTOR) was 0.63. A minimum of two factors (autovectors) was necessary to explain an average percentage of $63 \%$ of the variance observed.

There was a positive relation between production variables (Figure 1) and their relation to area, population, and gross domestic product (Autovector 1). However, there was a subgroup of mesoregions (Autovector 2) where there was a high number of milked cows per effective herd size (MCEH) and their relations (MCEH_area; MCEH_GDP; MCEH_pop) and low number of milked cows (MC) and amount of milk (AM). These mesoregions were less productive and less competitive. The production growth can be explained by the greater professional level and it was affected by environmental ${ }^{(17)}$, socioeconomic ${ }^{(22)}$, and technological factors ${ }^{(23)}$. 


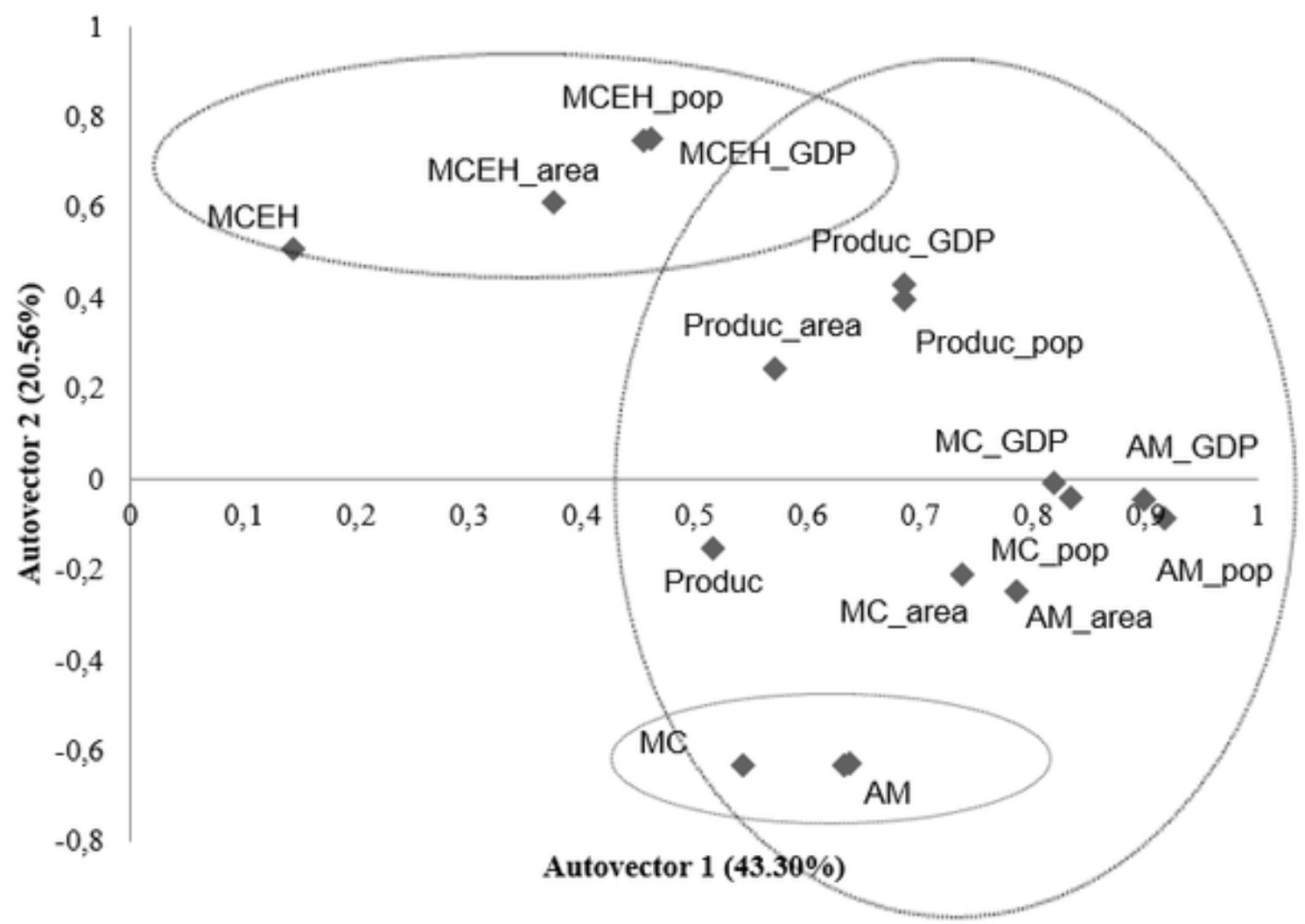

Figure 1. Graphical representation of the production factors per municipality within the mesoregion.

Subgroups are represented by circles.

Abbreviations see table 3.

The grouping of municipalities by amount of milk (1,000 liters) (Figure 2) showed that the high cluster (low production) consists of 439 municipalities belonging to all mesoregions. Cluster 2 (average to high production) consisted of 11 municipalities in Northwestern Rio-grandense (NW_RS), 16 in Western Catarinense (W_SC), two in Mideast Rio-grandense (ME_RS), 01 in Northeast Rio-grandense (NE_RS), two in southeast Riograndense (SE_RS), one in southwest Rio-grandense (SW_RS), and one in Southern Catarinense mesoregions (S_SC). High production (cluster 3) was formed by municipalities belonging to Northwestern Rio-grandense (NW_RS, 03) and Western Catarinense mesoregions (W_SC, 04). The fourth (average) and fifth (average to low) clusters were formed by 77 and 229 municipalities, respectively, in all 10 mesoregions.

The most productive group of municipalities included Casca, Marau, and Santo Cristo, in Northwestern Riograndense (NW_RS) and Concórdia, Coronel Freitas, Palmito, and São Lourenço do Oeste belonging to Western Catarinense (W_SC), with an average yield of 3492.14 liter/cow/year (equivalent to 11.44 liter/cow/day). Less productive municipalities were present in North Catarinense (N_SC), Southern Catarinense (S_SC) and Itajaí Valley Catarinense (Itajaí Valley_SC) with productivity of 1713.66 liter/cow/year (equivalent to $5.61 \mathrm{liter} / \mathrm{cow} /$ day) (Table 3). Production systems in these regions were characterized by family farming, dairy production and handmade cheese for consumption. 


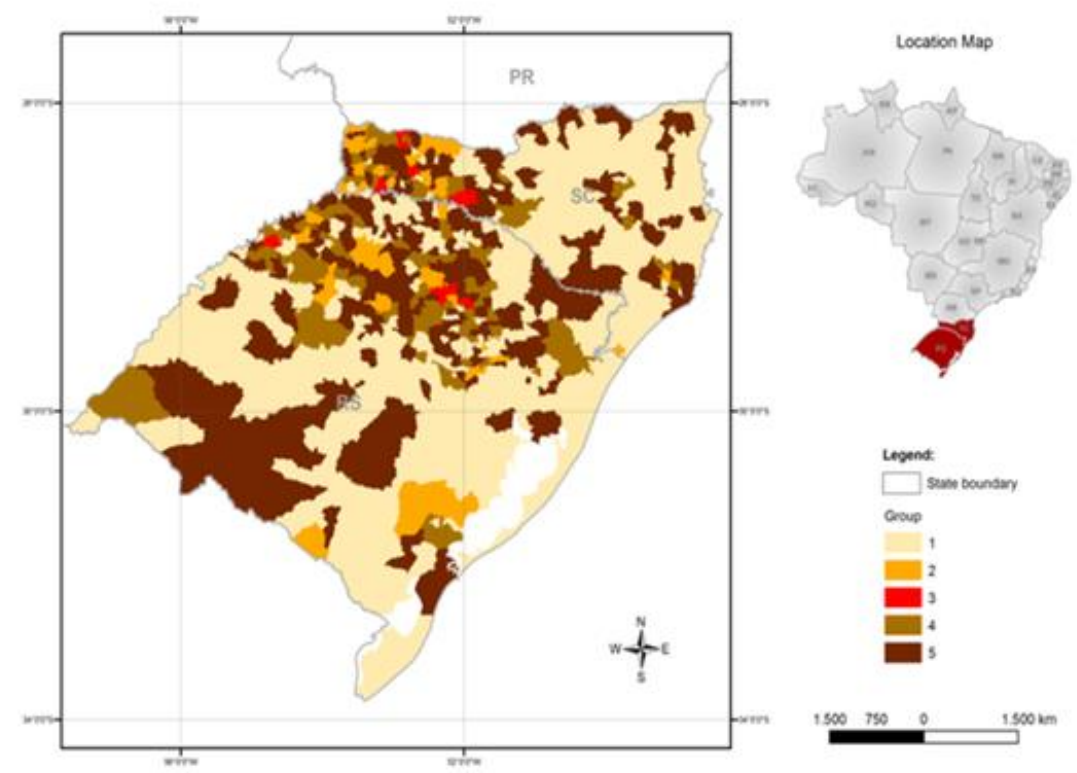

Figure 2. Clusters of municipalities formed by the amount of milk (1 000 liters).

Table 3. Mean production levels per cluster for the amount of milk (1,000 liters)

\begin{tabular}{lccccc}
\hline \multirow{2}{*}{ Variables } & $\mathbf{5}$ Cluster \\
\cline { 2 - 6 } & 1 & $\mathbf{2}$ & $\mathbf{3}$ & $\mathbf{4}$ & $\mathbf{5}$ \\
\hline MC & $1326.33^{\mathrm{e}}$ & $10283.76^{\mathrm{b}}$ & $15424.57^{\mathrm{a}}$ & $6321.68^{\mathrm{c}}$ & $3760.11^{\mathrm{d}}$ \\
AM & $2155.61^{\mathrm{e}}$ & $30348.56^{\mathrm{b}}$ & $50198.14^{\mathrm{a}}$ & $17292.68^{\mathrm{c}}$ & $8613.95^{\mathrm{d}}$ \\
Produc & $1713.66^{\mathrm{c}}$ & $3201.21^{\mathrm{ab}}$ & $3492.14^{\mathrm{a}}$ & $3050.18^{\mathrm{ab}}$ & $2570.86^{\mathrm{b}}$ \\
MCEH & $24.20^{\mathrm{a}}$ & $25.24^{\mathrm{a}}$ & $23.86^{\mathrm{a}}$ & $20.28^{\mathrm{a}}$ & $24.33^{\mathrm{a}}$ \\
MC_area & $0.11^{\mathrm{d}}$ & $0.36^{\mathrm{b}}$ & $0.47^{\mathrm{a}}$ & $0.31^{\mathrm{bc}}$ & $0.25^{\mathrm{c}}$ \\
AM_area & $0.20^{\mathrm{d}}$ & $1.17^{\mathrm{b}}$ & $1.59^{\mathrm{a}}$ & $0.92^{\mathrm{b}}$ & $0.63^{\mathrm{c}}$ \\
Produc_area & $0.25^{\mathrm{a}}$ & $0.13^{\mathrm{a}}$ & $0.11^{\mathrm{a}}$ & $0.18^{\mathrm{a}}$ & $0.21^{\mathrm{a}}$ \\
MCEH_area & $0.003^{\mathrm{a}}$ & $0.001^{\mathrm{a}}$ & $0.001^{\mathrm{a}}$ & $0.001^{\mathrm{a}}$ & $0.002^{\mathrm{a}}$ \\
MC_GDP & $0.02^{\mathrm{b}}$ & $0.09^{\mathrm{a}}$ & $0.08^{\mathrm{a}}$ & $0.07^{\mathrm{a}}$ & $0.06^{\mathrm{a}}$ \\
AM_GDP & $0.03^{\mathrm{d}}$ & $0.23^{\mathrm{b}}$ & $0.35^{\mathrm{a}}$ & $0.22^{\mathrm{bc}}$ & $0.14^{\mathrm{c}}$ \\
Produc_GDP & $0.03^{\mathrm{a}}$ & $0.02^{\mathrm{a}}$ & $0.03^{\mathrm{a}}$ & $0.04^{\mathrm{a}}$ & $0.04^{\mathrm{a}}$ \\
MCEH_GDP & $0.0004^{\mathrm{a}}$ & $0.0002^{\mathrm{a}}$ & $0.0002^{\mathrm{a}}$ & $0.0002^{\mathrm{a}}$ & $0.0004^{\mathrm{a}}$ \\
MC_pop & $0.25^{\mathrm{b}}$ & $1.29^{\mathrm{a}}$ & $1.12^{\mathrm{a}}$ & $1.07^{\mathrm{a}}$ & $0.86^{\mathrm{a}}$ \\
AM_pop & $0.43^{\mathrm{d}}$ & $3.60^{\mathrm{ab}}$ & $4.49^{\mathrm{a}}$ & $3.20^{\mathrm{b}}$ & $2.02^{\mathrm{c}}$ \\
Produc_pop & $0.35^{\mathrm{a}}$ & $0.38^{\mathrm{a}}$ & $0.36^{\mathrm{a}}$ & $0.61^{\mathrm{a}}$ & $0.62^{\mathrm{a}}$ \\
MCEH_pop & $0.005^{\mathrm{a}}$ & $0.003^{\mathrm{a}}$ & $0.002^{\mathrm{a}}$ & $0.004^{\mathrm{a}}$ & $0.01^{\mathrm{a}}$ \\
\hline Number of observations & 441 & 34 & 7 & 78 & 229 \\
\hline
\end{tabular}

Abbreviations: MC:milked cows; AM: amount of milk; Produc: productivity; MCEH: milked cows per effective herd; MC_area: milked cows per area; MC_GDP: milked cows per gross

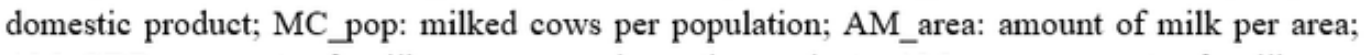
AM_GDP: amount of milk per gross domestic product; AM_pop: amount of milk per population; Produc_area: productivity per area; Produc_GDP: productivity per gross domestic product; Produc_pop: productivity per population; $\mathrm{MCEH}_{-}$area: milked cows per effective herd per area; MCEH_GDP: milked cows per effective herd per gross domestic product; MCEH_pop: milked cows herd per effective population. 
In cluster 3, composed of the more productive municipalities, there was no confounding with other clusters (100\%). Clusters 2, 4, 5 and 1, the second, third, fourth and fifth most productive ones, showed high levels of discrimination, $97.6 \%, 98.7 \%, 97.82 \%$, and $97.1 \%$ respectively. Therefore, $98.24 \%$ of municipalities were correctly allocated in their clusters due to production levels. Unlike the poor discrimination among mesoregions $(35.67 \%)$, grouping by municipality due to the similarity in production enables high differentiation among the groups formed. Therefore, political units within the administrative mesoregions had different production and may be affected by several factors.

These results contrasted with those obtained in the discriminant analysis for mesoregion, showing that this was due to the diversified productions in the municipalities, resulting in similar production levels. The production in the municipalities was the result of the genetic makeup of the herds ${ }^{(24)}$ and the interaction with soil and climatic $^{(13)}$, socioeconomic ${ }^{(22)}$, and technological ${ }^{(2)}$ variables. These factors help to deepen the understanding of the spatial distribution of milk production ${ }^{(5)}$.

The amount of milk produced, productivity, and number of cows milked explained $93.01 \%, 12.11 \%$, and $20.72 \%$ of the variation among clusters (Table 4). The quantitative variables (AM and MC) better explained the difference between clusters compared to the productivity variables (Produc). These variables were important to determine the productive and economic efficiency of dairy farming ${ }^{(25)}$.

Table 4. Production variables that explain the differences between the clusters formed by the amount of milk ( 1,000 liters)

\begin{tabular}{lccc}
\hline Variable & $\begin{array}{c}\text { Partial } \\
\text { R-Square }\end{array}$ & F Value & Pr $>$ F \\
\hline AM & 0.9301 & 2591.71 & $<.0001$ \\
Produc & 0.1211 & 26.8 & $<.0001$ \\
MC & 0.2072 & 50.77 & $<.0001$ \\
AM_pop & 0.0634 & 13.13 & $<.0001$ \\
Produc_pop & 0.0452 & 9.16 & $<.0001$ \\
MC_area & 0.0492 & 9.99 & $<.0001$ \\
Produc_area & 0.0607 & 12.48 & $<.0001$ \\
MC_pop & 0.0277 & 5.5 & 0.0002 \\
AM_GDP & 0.0175 & 3.43 & 0.0086 \\
MC_GDP & 0.0378 & 7.56 & $<.0001$ \\
\hline
\end{tabular}

Abbreviations see Table 3.

Environmental and socioeconomic factors were used to discriminate the groups of municipalities formed. The discriminatory power of these factors ranged from $59.46 \%$ to $85.71 \%$ with an average of $72.58 \%$. Agricultural management with rotational grazing was the main management variable explaining the variation among clusters $(42.88 \%)$. Clusters that showed the highest number of properties that perform the management of rotational grazing had significantly higher production; thus, nutrition was a key factor for animal production. Strategies to improve nutrition ${ }^{(26)}$ and nutritional imbalances and excesses ${ }^{(27)}$ have been widely studied to circumvent the negative effects on animal production.

Farmers with off-farm jobs and other agricultural activities significantly explain the variation among clusters (Table 5). Producer with non-agricultural activities on the farm did not help to explain this variation. Farm owners with off-farm jobs and those who had farming with other agricultural activities influenced in higher productivity significantly. The practice of off-farm or other activity affected specialization and production and productive efficiency ${ }^{(28)}$. 
Table 5. Environmental and socioeconomic variables that explain the differences among the clusters formed

\begin{tabular}{|c|c|c|c|}
\hline Variables & $\begin{array}{c}\text { Partial } \\
\text { R-Square }\end{array}$ & F Value & $\operatorname{Pr}>\mathbf{F}$ \\
\hline Farmers with off-farm jobs & 0.0147 & 2.36 & 0.0518 \\
\hline Farmers with other agricultural activities & 0.0284 & 4.61 & 0.0011 \\
\hline Forests planted with forest trees per area & 0.0118 & 1.89 & 0.111 \\
\hline Water resources in establishments with springs and protected forest & 0.0251 & 4.07 & 0.0029 \\
\hline Water resources in establishments with springs without protected forest & 0.0162 & 2.61 & 0.0347 \\
\hline Water resources in establishments with rivers or streams and protected forest & 0.0196 & 3.15 & 0.0139 \\
\hline Water resources in establishments with rivers or streams without protected forest & 0.0338 & 5.53 & 0.0002 \\
\hline Water resources in establishments with natural lakes and/or ponds and protected forest & 0.0196 & 3.15 & 0.0139 \\
\hline Water resources in establishments with natural lakes and/or ponds without protected forest & 0.0488 & 8.11 & $<.0001$ \\
\hline Technical guidance received by the government (federal, state, or municipal) & 0.0121 & 1.94 & 0.1021 \\
\hline Technical guidance sought by the producer him/herself & 0.0242 & 3.92 & 0.0038 \\
\hline Technical guidance received by private planning & 0.0319 & 5.2 & 0.0004 \\
\hline Men responsible for the farm for 5 to 10 years & 0.0254 & 4.12 & 0.0027 \\
\hline Management of agricultural pasture rotation & 0.4288 & 118.6 & $<.0001$ \\
\hline Municipal human development index & 0.0238 & 3.86 & 0.0042 \\
\hline Altitude (meters above sea level) & 0.0405 & 6.67 & $<.0001$ \\
\hline Mean temperature & 0.0497 & 8.26 & $<.0001$ \\
\hline Solar radiation & 0.0111 & 1.78 & 0.1321 \\
\hline
\end{tabular}

Farms with water sources (springs, rivers, streams, and ponds and/or reservoirs), or protected forests did not explain the difference among the clusters. Water availability had direct effects on forage and animal production $^{(29)}$. For Nardone et al. ${ }^{(30)}$, improving information on biophysical vulnerability contributes to optimize production and address the effects of climate change. This understanding by the producer about the risks coming from drought and by the government to invest in irrigation ensures the application of better practices for increasing productivity ${ }^{(31)}$.

The climatic factors that explained the majority of differences among groups were temperature and altitude, as it correlates with temperature, because they alter the comfort zone of the animals, affecting their physiology, metabolism, and endocrinology. An increase in these factors have an effect on the animal organism in several ways, determining, in general, decreased production, which may affect the quantity and quality of milk ${ }^{(17)}$, reproductive physiology ${ }^{(16)}$, mortality rates $^{(32)}$, and the breeds ${ }^{(14)}$.

In terms of management factors, men that has been responsible for the farm for 5 to10 years and technical guidance received by the government, sought by the producer him/herself and private planning explained most variations between clusters. The clusters that received less technical guidance were significantly less productive. There was, at the moment, a restructuring of activities and job responsibilities going on ${ }^{(33)}$; however, cultural and historical issues still determine the man should be the farm manager and the woman a collaborator. Mapiye et al. ${ }^{(22)}$ also observed that cattle management was performed mostly by men.

The municipal human development index was the socioeconomic variable that best explained variation among clusters. The higher human development index, the greater consumption and demand for product quality. It also implies a higher degree of understanding and application of methods in production processes. When technical guidelines were well understood and applied to the property, these could result not only in higher production $^{(23)}$ but in improved animal welfare ${ }^{(34)}$. The process of learning about new technologies ${ }^{(35)}$, besides the understanding of productivity and extension services ${ }^{(36)}$ contribute to the management and development of more productive systems. Policies for the development of human capital ${ }^{(37)}$ were important actions for economic and social development and consequently production ${ }^{(38)}$.

In general terms, the results showed the importance of knowing the effects of the environment on the animals as a mean to understand the different production levels ${ }^{(39)}$. Consequently, technologies in animal breeding ${ }^{(15)}$, 
management ${ }^{(28)}$, and reproductive ${ }^{(16)}$ processes become important tools to reduce the negative effects of the environment on the production levels.

\section{Conclusions}

The analysis evidenced differences among the mesoregions of Rio Grande do Sul and Santa Catarina states. The production factors were the most important in the discrimination between the clusters formed. The amount of milk, productivity, milked cows, and management with agricultural pasture rotation were the variables that best explained the differences among the mesoregions. The heterogeneity of the production and environmental components revealed peculiarities specific to each mesoregion. Therefore, it is necessary to design and program technological innovations specific to each mesoregion to maximize production efficiency and minimize environmental effects on dairy herds.

\section{References}

1. Herrero M, Thornton PK, Notembaert A, Wood S, Msangi S, Freeman HA, Bossio D, Dixon J, Peters M, Van de Steeg J, Lynam J, Parthasarathy RAO, MacMillan S, Gerard B, McDermotT J, Seré C, Rosegrant M. Smart Investments in Sustainable Food Production: Revisiting Mixed Crop-Livestock Systems. Sci. 2010; 327(5967): 822-827. Available from: http://dx.doi.org/10.1126/science.1183725

2. Costa JHC, Hötzel MJ, Longo C, Balcão LF. A survey of management practices that influence production and welfare of dairy cattle on family farms in southern Brazil. J. Dairy Sci. 2013; 96 (1): 307-317. Available from: http://dx.doi.org/10.3168/jds.2012-5906

3. Zoccal R, Alves ER, Gasques J.C. Diagnosis of dairy farming country. [Internet]. Embrapa Dairy Cattle; 2012 [cited 2012 Jully 12]. Available from: http://www.cnpgl.embrapa.br/nova/Plano Pecuario 2012.pdf

4. Joost S, Colli L, Baret PV, Garcia JF, Boettcher PJ, Tixier-Boichard M, Ajmone-Marsan P, Globaldiv C. Integrating geo-referenced multiscale and multidisciplinary data for the management of biodiversity in livestock genetic resources. Anim. Genet. 2010; 41(supl.1): 47-63. Available from: http://dx.doi.org/10.1111/j.1365-2052.2010.02037.x.

5. Lopes FB, Silva MC, Miyagi ES, Fioravanti MCS, Facó O, Guimarães RF, Júnior OAC, McManus CM. Spatialization of climate, physical and socioeconomic factors that affect the dairy goat production in Brazil and their impact on animal breeding decisions. Pesq. Vet. Bras. 2012; 32(), 1073-1081. Available from: http://dx.doi.org/10.1590/S0100-736X2012001100001

6. Brazilian Institute of Geography and Statistics (IBGE). Agricultural Census, 2006. [Internet]. Brazilian Institute of Geography and Statistics, Rio de Janeiro, RJ; 2006 [cited 2013 July 13]. Available from: http://www.ibge.gov.br

7. United Nations Development Programme (UNDP). Atlas of Human Development in Brazil. [Internet]. United Nations Development Programme, New York, NY; 2010 [cited 2012 November 30]. Available from: http://www.pnud.org.br/atlas/ranking/IDH-

M\%2091\%2000\%20Ranking\%20decrescente\%20(pelos\%20dados\%20de\%202000).htm

8. National Institute of Meteorology (INMET). [Internet]. National Institute of Meteorology, Brasília, DF; 2012 [cited 2012 December 15]. Available from: www.inmet.br

9. National Institute for Space Research (INPE). [Internet]. National Institute for Space Research, São José 
dos Campos, SP; 2012 [cited 2012 December 12]. Available from: www.inpe.gov.br

10. United States Geological Survey (USGS). [Internet]. United States Geological Survey, Reston, VA; 2012 [cited 2012 November 01]. Available from: www.usgs.gov

11. Kaiser HF. A second generation little Jiffy. Psychometrika. 1970; 35(4): 401-415.

12. Lachenbruch PA. Discriminant diagnosis. Biometrics.1997; 53(4):1284-1292.

13. Fuhrer J, Smith P, Gobiet A. Implications of climate change scenarios for agriculture in alpine regions - A case study in the Swiss Rhone catchment. Sci. Total Environ. 2014; 493: 1232-1241. Available from: http://dx.doi.org/10.1016/j.scitotenv.2013.06.038

14. Liang D, Wood CL, McQuerry KJ, Ray DL, Clark JD, Bewley JM. Influence of breed, milk production, season, and ambient temperature on dairy cow reticulorumen temperature. J. Dairy Sci. 2013; 96(8): 50725081. Available from: http://dx.doi.org/ 10.3168/jds.2012-6537

15. Ferraz JBS, Eler JP. Public Private x partnership in the development of research in animal breeding. Braz. J. Anim. Sci. 2010; 39: 216-222. Available from: http://dx.doi.org/10.1590/S1516-35982010001300024

16. Hansen PJ, Fuquay JW. 2011. Stress in Dairy Animals | Heats Stress: Effects on Reproduction. Encyclopedia Dairy Sci. 2011; 4: 567-574. Available from: http://dx.doi.org/10.1016/B978-0-12-3744074.00468-4

17. Staples CR, Thatcher WW. 2011. Stress in Dairy Animals | Heat Stress: Effects on Milk Production and Composition. Encyclopedia Dairy Sci. 2011; 2: 561-566. Available from: http://dx.doi.org/10.1016/B978-0$12-374407-4.00467-2$

18. Siqueira KB, Carneiro AV. 2012. Conjuntura do mercado lácteo. [Internet]. Embrapa Gado de Leite, Juiz de Fora, MG; 2012 [cited 2012 August 01]. Available from: http://guernsey.cnpgl.embrapa.br/sites/default/files/2012 04 indicadores leite.pdf

19. Gerbens-Leenes PV, Nonhebel S, Krol MS. Food consumption patterns and economic growth. Increasing affluence and the use of natural resources. Appetite. 2010; 55(3): 597-608. Available from: http://dx.doi.org/10.1016/j.appet.2010.09.013

20. Brazilian Institute of Geography and Statistics (IBGE). [Internet]. Brazilian Institute of Geography and Statistics, Rio de Janeiro, RJ; 2011 [cited 2014 July13]. Available from: http://www.ibge.gov.br

21. Fundação de Economia e Estatística (FEE). [Internet]. Fundação de Economia e Estatística, Canoas, RS; 2011. [cited 2012 March 20]. Available from: http://www.fee.rs.gov.br

22. Mapiye C, Chimonyo M, Dzama K, Raats JG, Mapekula M. Opportunities for improving Nguni cattle production in the smallholder farming systems of South Africa. Livest. Sci. 2011; 124(1-3): 196-204. Available from: http://dx.doi.org/10.1016/j.livsci.2009.01.013

23. Main DCJ, Leach KA, Barker ZE, Sedgwick AK, Maggs CM, Bell NJ, Whay HR. Evaluating an intervention to reduce lameness in dairy cattle. J. Dairy Sci. 2012; 95(6): 2946-2945. Available from: http://dx.doi.org/10.3168/jds.2011-4678

24. Vance ER, Ferris CP, Elliott CT, Hartley HM, Kilpatrick DJ. Comparison of the performance of HolsteinFriesian and Jersey $\mathrm{x}$ Holstein-Friesian crossbred dairy cows within three contrasting grassland-based systems of milk production. Livest. Sci. 2013; 151(): 66-79. Available from: http://dx.doi.org/10.1016/j.livsci.2012.10.011

25. Roibas D, Alvarez A. Impact of genetic progress on the profits of dairy farmers. J. Dairy Sci. 2010; 93(9): 4366-4373. Available from: http://dx.doi.org/10.3168/jds.2010-3135 
26. Auldist MJ, Marett LC, Greenwood JS, Hannah M, Jacobs JL, Wales WJ. Effects of different strategies for feeding supplements on milk production responses in cows grazing a restricted pasture allowance. J. Dairy Sci. 2013; 96(2): 1218-1231. Available from: http://dx.doi.org/10.3168/jds.2012-6079

27. Lean IJ, Westwood CT, Golder HM, VermunT JJ. Impact of nutrition on lameness and claw health in cattle. Livest. Sci. 2013; 156(1-3): 71-78. Available from: http://dx.doi.org/10.1016/j.livsci.2013.06.006

28. Khanal AR, Gillespie J, McDonald J. Adoption of technology, management practices, and production systems in US milk production. J. Dairy Sci. 2010; 93(12): 6012-6022. Available from: http://dx.doi.org/10.3168/jds.2010-3425

29. Crane TA, Roncoli C, Hoogenboom G. Adaptation to climate change and climate variability: The importance of understanding agriculture as performance. J. Life Sci. 2011; 57(3-4): 179-185. Available from: http://dx.doi.org/10.1016/j.njas.2010.11.002

30. Nardone A, Ronchi B, Lacetera N, Ranieri MS, Bernabucci U. Effects of climate changes on animal production and sustainability of livestock systems. Livest. Sci. 2010; 130(1-3): 57-69. Available from: http://dx.doi.org/10.1016/j.livsci.2010.02.011

31. Milgroom J, Giller KE. Courting the rain: Rethinking seasonality and adaptation to recurrent drought in semi-arid southern Africa. Agr. Syst. 2013; 118: 91-104. Available from: http://dx.doi.org/10.1016/j.agsy.2013.03.002

32. Vitali A, Segnalini M, Bertocchi L, Bernabucci U, Nardone A, Lacetera N. Seasonal pattern of mortality and relationships between mortality and temperature-humidity index in dairy cows. J. Dairy Sci. 2009; 92(8): 3781-3790. Available from: http://dx.doi.org/10.3168/jds.2009-2127

33. Hovorka AJ. Women/chickens vs. men/cattle: Insights on gender-species intersectionality. Geoforum. 2012; 43(4): 875-884. Available from: http://dx.doi.org/ 10.1016/j.geoforum.2012.02.005

34. Paranhos da Costa MJR, Huertas SM, Gallo C, Dalla Costa OA. Strategies to promote farm animal welfare in Latin America and their effects on carcass and meat quality traits. Meat Sci. 2012; 92(3), 221-226. Available from: http://dx.doi.org/10.1016/j.meatsci.2012.03.005

35. Scherzer J, Buchanan MF, Morre JN, White SL. Teaching Veterinary Obstetrics Using Three-Dimensional Animation Technology. J. Vet. Med. Educ. 2010; 37(3): 299-303. Available from: http://dx.doi.org/10.3138/jvme.37.3.299

36. Volanis M, Stefanakis A, Hadjigeorgiou I, Zoiopoulos P. Supporting the extensive dairy sheep smallholders of the semi-arid region of Crete through technical intervention. Trop. Anim. Health Prod. 2007; 39(5): 325-334. Available from: http://dx.doi.org/10.1007/s11250-007-9019-z

37. Davis K, Nkonya E, Kato E, Mekonnen DA, Odendo M, Miiro R, Nkuba J. Impact of Farmer Field Schools on Agricultural Productivity and Poverty in East Africa. [Internet]. International Food Policy Research Institute, Washington, DC; 2010 [cited 2012 February 20]. Available from: http://www.ifpri.org/publication/impact-farmer-field-schools-agricultural-productivity-and-poverty-eastafrica

38. Mendola M. Migration and technological change in rural households: Complements or substitutes? J. Dev. Econ. 2008; 85(1-2) 150-175. Available from: http://dx.doi.org/10.1016/j.jdeveco.2006.07.003

39. Andreu-Vázquez CA, Gracia-Ispierto I, López-Gatius F. Photoperiod length and the estrus synchronization protocol used before AI affect the twin pregnancy rate in dairy cattle. Theriogenology. 2012; 78(6): 12091216. Available from: http://dx.doi.org/10.1016/j.theriogenology.2012.05.014. 